\title{
Identification of Geothermal Potential Based on Fault Fracture Density (FFD), Geological Mapping and Geochemical Analysis, Case Study : Bantarkawung, Brebes, Central Java
}

\author{
Oktoberiman $^{\mathrm{a} *}$, Dimas Aji Ramadhan $\mathrm{P}^{\mathrm{a}}$, Fajar Rizki W ${ }^{\mathrm{a}}$, Rizal Tawakal A ${ }^{\mathrm{a}}$ \\ ${ }^{a}$ University of Jenderal Soedirman. Jl, Mayjen Sungkono KM 5 Purbalingga, Indonesia
}

\begin{abstract}
Insufficient of conventional energy production today in Indonesia, encouraging all elements to discover an alternative energy. Geothermal is one of big potential alternative energy in Indonesia regarding the conditon of geological setting in Indonesia which has 129 active volcanoes. Bantarkawung is located in the western of Mount Slamet where hot spring occured as geothermal manifestation. This indicate geothermal potential in that area. This research is aimed to identify geothermal potential that lies in bantarkawung using Fault Fracture Density (FFD), Geological Mapping and Geochemical analysis. Based on FFD analysis known that anomaly area is located at central and northeast of research area, and based on geological mapping known that area composed by mudstone unit and sandstone unit, water temperature of research area is $43{ }^{\circ} \mathrm{C}$ to $62{ }^{\circ} \mathrm{C}$, by using geochemical analysis of major ions $\mathrm{HCO}_{3}{ }^{-}, \mathrm{Cl}^{-}, \mathrm{SO}_{4}{ }^{2-}$ known that the type of hot water is bicarbonate water which characterized as an outflow zone of geothermal system.
\end{abstract}

Keywords: Bantarkawung; FFD; geochemichal analysis; geothermal; hot springs

\section{Introduction}

Research area is located in Bantarkawung area with extens about $12 \mathrm{Km}^{2}$ consist of four villages (Karangpari, Waru, Pangebatan, and Telaga). Bantarkawung which located in Brebes region is interesting area to be researched especially for geothermal study. This area has hot springs water which indicate surface of geothermal system, interesting lithology and complex geological structures [1] Geothermal potential in this research area influenced by Java tectonic which has well-organized patterns. In general there are three patterns of structures that develope in Java namely Northeast-Southwest (NE-SW) called meratus pattern, North-south (N-S) direction or Sunda pattern and East-West (E-W) direction or called Java pattern.

\footnotetext{
* Corresponding author. Tel.: +62 87771430301

E-mail address: dimasrp34@yahoo.com
} 


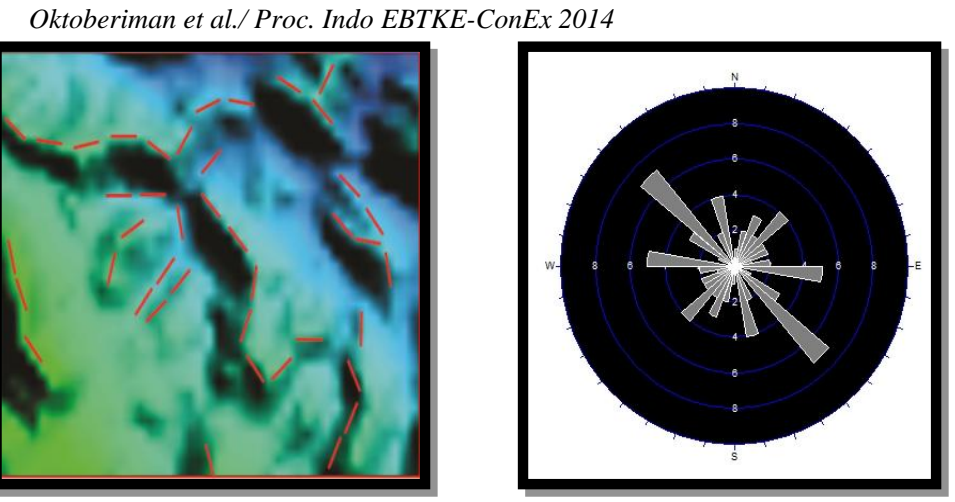

Figure 1. Pattern Straightness of The Srtm and Roset Diagram.

Regional Strathigraphy of research area consist of Rambatan formation and Halang formation. The Bottom of Rambatan formation consist of calcareous sandstone and conglomerate which alternate each other with thin layers marl and shale, while on top consist of calcareous sandstone colored light gray until gray blue. Halang formation consist of tuffaceous sandstone, conglomerate, marl, and claystone which alternate each other and well layered [1]

\section{Methods}

Identification of geothermal in this research conducted by using FFD analysis, geological mapping and geochemical analysis of hot water as a surface manifestation in research area.

\subsection{Fault Fracture Density (FFD)}

FFD analysis is a method of remote sensing that aims to find zone or area of geothermal based on density of the fractures that exist in the research area. FFD method is gained from lineaments of structure which illustrate reflection of topography such as river lineaments, valley lineaments, fault or fracture structure, lithology contact, and geothermal manifestations appearence, therefore known lineaments trend that classified on $4 \times 3 \mathrm{~km}$ grid of research area as characteristic of geothermal manifestations.[2]

\subsection{Geological mapping}

Geological mapping is done to make geological map. Geological map is a map that provides an overview of the entire deployment and arrangement of rock layers and it can provide three-dimensional reflection of the composition of the rocks in the subsurface. Geological mapping is a method by conducting research directly to the geological aspects in field of research area such as lithology, stratigraphy, and structure that can explain the existence of hot springs in the research area and also measuring the temperature of the hot springs and temperature of the river.

\subsection{Geochemical analysis}

The geochemical analysis consist of measuring and analysis the content of chemical composition so that it can be determined that there is a relationship with the presence of hot springs and geothermal resource around the research area. [3] Geochemical analysis is conducted to gain the contain of chemical element of the water such as $\mathrm{HCO}_{3}{ }^{-}$, $\mathrm{SO}_{4}{ }^{2-}, \mathrm{Na}, \mathrm{Ca}, \mathrm{Mg}, \mathrm{K}, \mathrm{Cl}, \mathrm{B}$ and $\mathrm{pH}$. The result of data will be put in trilinear pipper diagram to know the hot water type. 


\section{Results and discussion}

\subsection{Fault Fracture Density (FFD)}

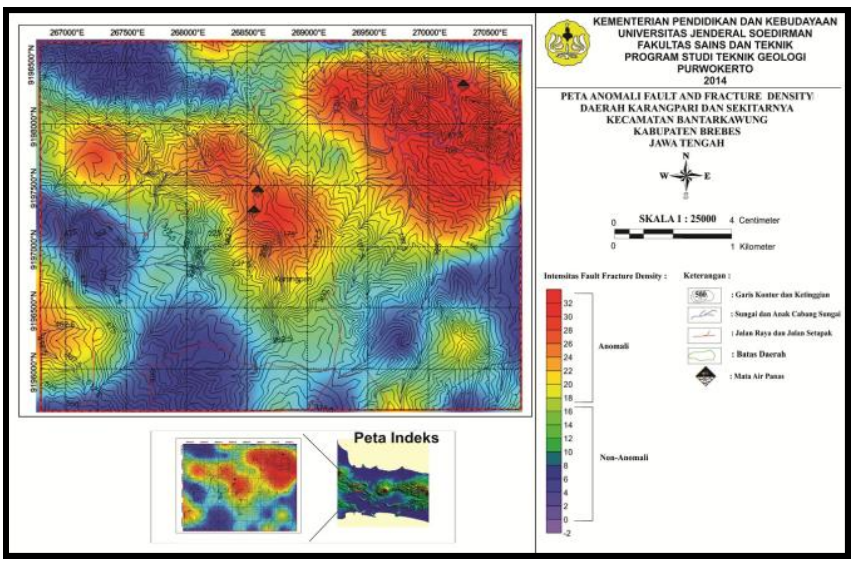

Figure 2. Fault and Fracture Density Map of research area.

Based on the calculation of the distribution intensity of the structure by using FFD, Bantarkawung regions can be divided into two structural intensity areas which are high intensity area and low intensity. High intensity area is shown by yellow to red colors, while low intensity area is shown by green - blue colors (Figure 2). Areas with high intensity are located on center and northeast of research area. Green areas are non-anomalous areas. Areas of highvalue associated with the heat source rock, because the intensity of the structure associated with the drainage of fluid (steam heat). The appearance of some fault topography indicates the deformation control and fracture in this area.

Fault and Fracture Density (FFD) map in Figure 1 show anomaly of density of structure (red area) which located on center and northern of research area. The density of structure is related with geothermal manifestations because higher density of structure is directly equal to higher potential of geothermal. [4].

\subsection{Geological mapping}

The Geological mapping show that the research area consist of two lithology units, which are mudstone unit and sandstone unit. Geology map is shown in Figure 3.

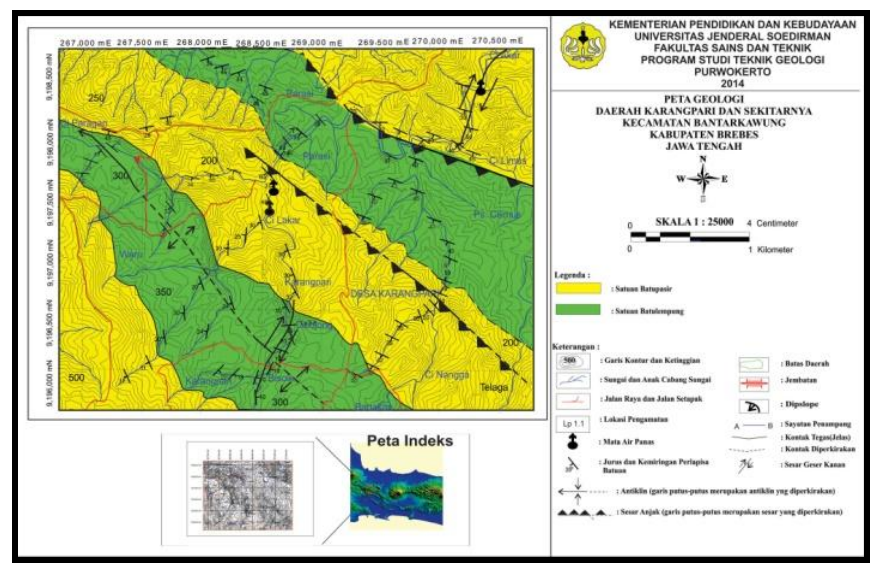

Figure 3. Geology map Karangpari area and its nearby. 
The geological structures which control the research area are Pangebatan left thrust slip fault, Karangpari left thrust slip fault, Pangebatan right slip fault and Bisole right normal slip fault. The Mudstone unit is covered about $38.1 \%$ from total of research area that consist of mudstone alternate with sandstone and intercalate with limestone and breccia, the average thickness of mudstone is about $1.5 \mathrm{~m}$, while the thickness of sandstone is about $30 \mathrm{~cm}$ to $100 \mathrm{~cm}$. Mudstone is thinning upward while sandstone is thickening upward. Mudstone is dark gray, low carbonate and compact. Sandstone is light gray-green in color, medium to coarse grain, carbonate, poor sorted, mineral composition are quartz, feldspar, and mafic minerals, graded bedding structure. Limestone is light gray, very fine grain, very compact, place on top in this unit. Breccia is gray-dark, gravel-pebble grain, sub angular - angular fragment, carbonate, poor sorted, compact, matrix is composed by medium sandstone. Sandstone unit consist of alternating of sandstone and mudstone with sandstone dominated. In the lower sandstone, the average thickness is about $1 \mathrm{~m}$ to $1.5 \mathrm{~m}$ with coarser until fragmented in grain.
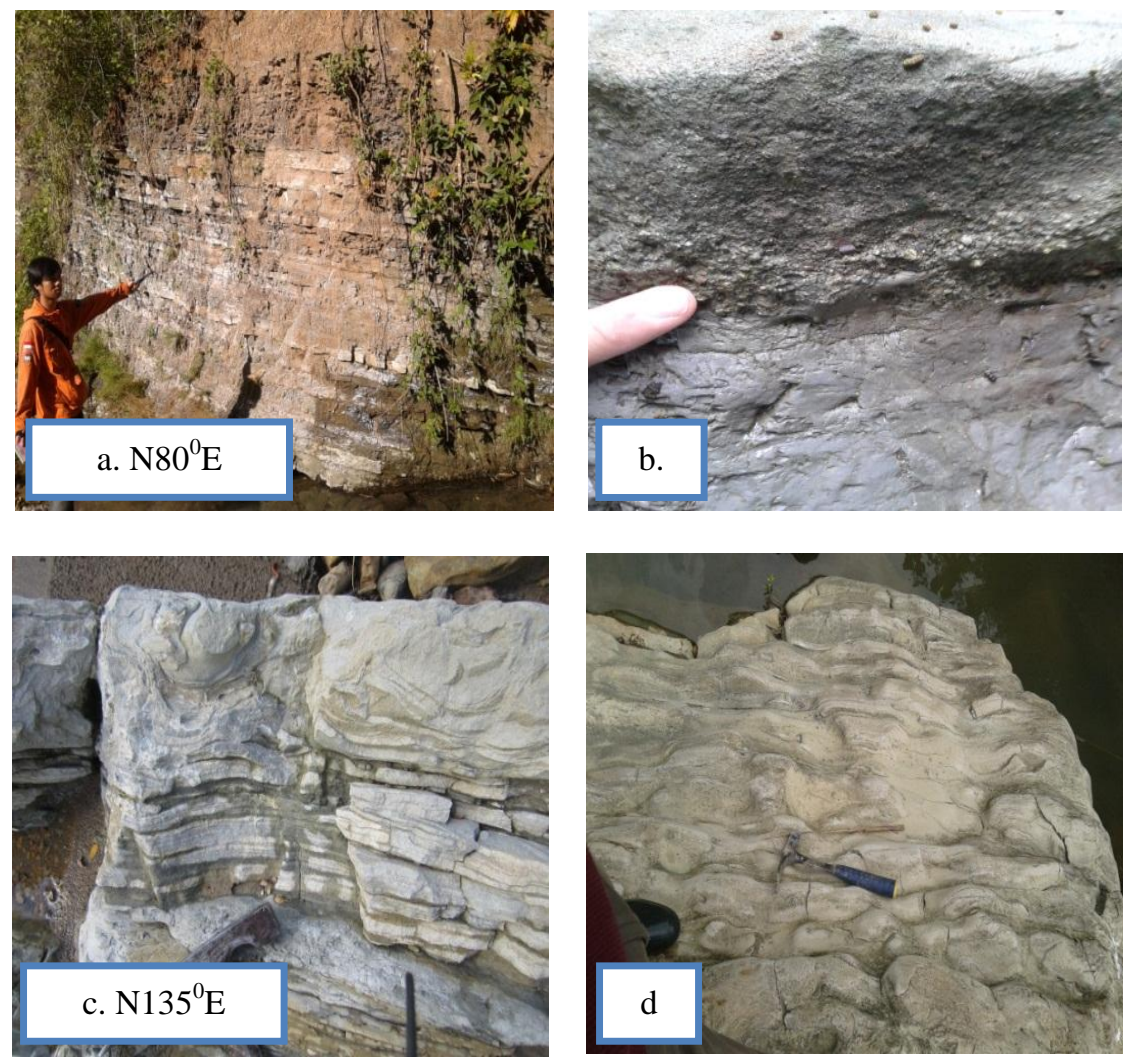

Figure 4. Sandstone-mudstone outcrop (a), graded bedding structure (b), paralel lamination and load structure (c), flute cast structure (d).

The sandstone's layer pattern is fining and thinning upward while sediment structures are graded bedding, paralel lamination, wavy lamination, convolute, load cast, and bioturbation. The mudstone is colored dark, carbonate, compact, and fresh in outcrop. The sandstone is fine-coarse grain, well-poor sorted, open-closed fabric, igneous rocks fragment, minerals are quartz, feldspar, and mafic minerals. The conglomerate colored gray-black, gravelpebble grain, rounded-subrounded fragment, open fabric, carbonate, poor sorted, compact, fragment igneous rocks, sedimentary rocks, matrix : medium sandstone. The geological structures in research area are Pangebatan left thrust slip fault, Karangpari left thrust slip fault, Pangebatan right slip fault and Bisole right normal slip fault. 

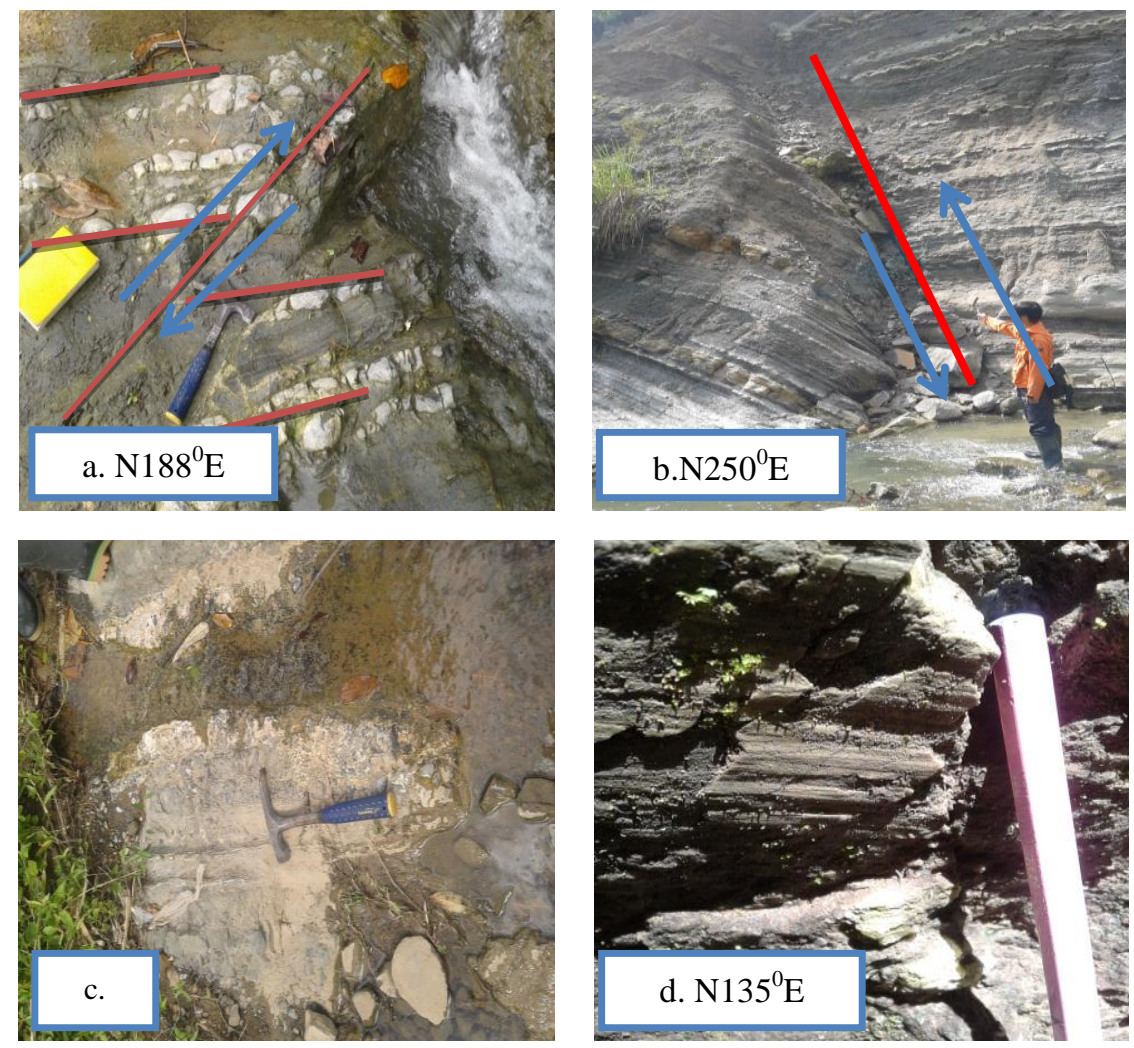

Figure 5. Minor fault (a and b), brecciation (c), scratch line (d).

The manifestations of hot springs are located on the center and northern of research area, and have temperature are $45{ }^{\circ} \mathrm{C}, 43{ }^{\circ} \mathrm{C}$, and $62{ }^{\circ} \mathrm{C}$. The hot spring manifestation lies on the sandstone unit. The presence of hot springs also controlled by the characteristics of geological aspects which stand on the research area. Sandstone unit has better permeability rather than Mudstone unit. The better permeability can be a good way and good media so that the hot water can be passed. Furthermore, the amount of structures which lies on the standstone unit also create secondary permeability so that it can be more effective media to the hot springs in flowing horizontally and vertically. 

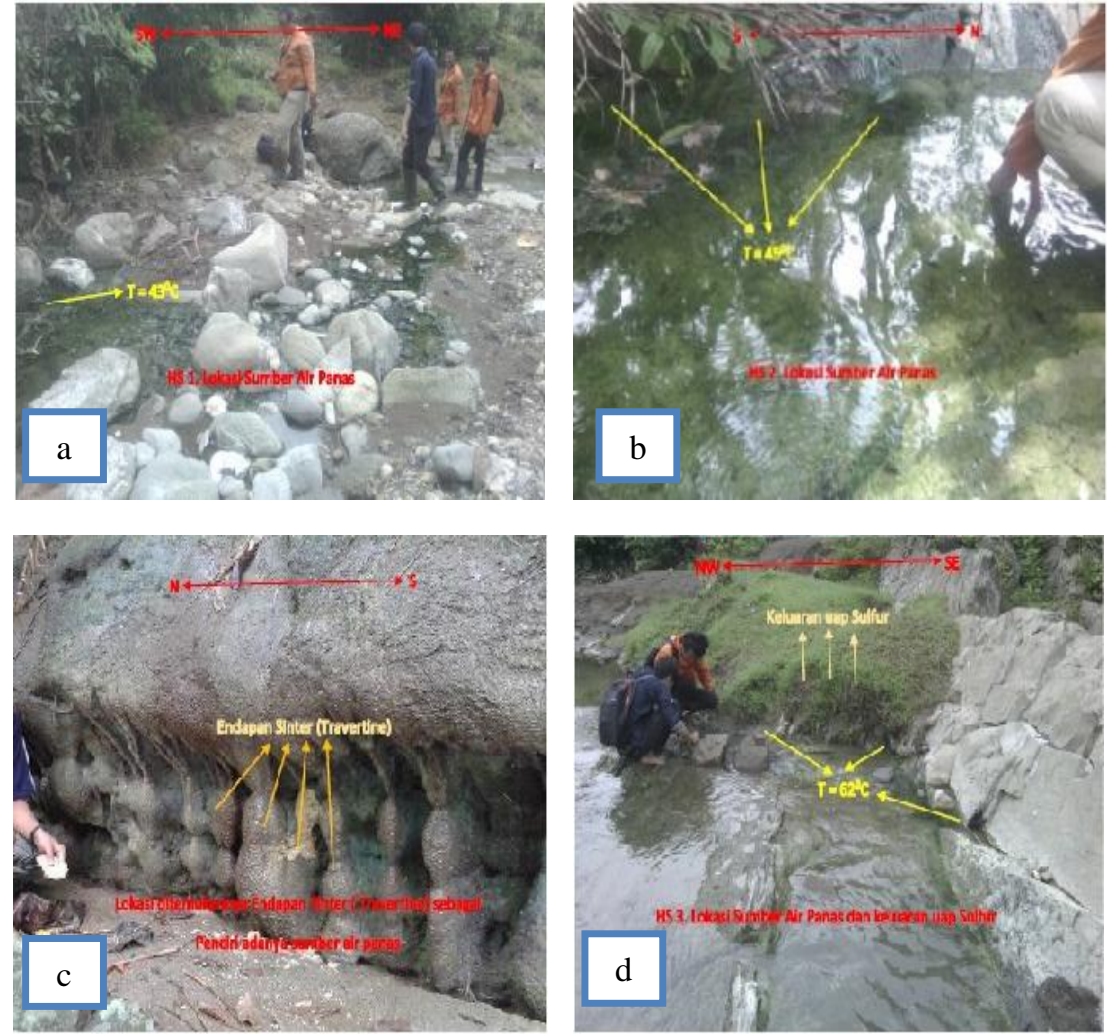

Figure 6. HS1 Location (a), HS2 Location (b), Sinter travertin (c), HS3 Location (d)..

Table 1. Data maesurements of hot spring water and cold water.

\begin{tabular}{ccccc}
\hline No. Sample & \multicolumn{2}{c}{$\begin{array}{c}\text { Coordinates } \\
\text { UTM }\end{array}$} & $\begin{array}{c}\text { Elev. } \\
(\mathrm{m})\end{array}$ & $\begin{array}{c}\text { Temp } \\
\left({ }^{\circ} \mathrm{C}\right)\end{array}$ \\
\hline HS1 & $26590 \mathrm{ME}$ & $9197402 \mathrm{MN}$ & 162.5 & 43 \\
HS2 & $268539 \mathrm{ME}$ & $9197386 \mathrm{MN}$ & 162.5 & 45 \\
HS3 & $270343 \mathrm{ME}$ & $9198341 \mathrm{MN}$ & 87.5 & 62 \\
CW1 & $268925 \mathrm{ME}$ & $9198003 \mathrm{MN}$ & 125 & 26 \\
\hline
\end{tabular}

Table 2. Field descriptions of hot springs water (HS1-3), and cold water stream (CW1).

\begin{tabular}{cc}
\hline No Sample & Brief description \\
\hline HS1 & $\begin{array}{r}\text { Clear, slightly brackish, emit gas bubbles, slight smell of sulfur. The hot water temperature at the larger ponds } \\
\text { were } 43{ }^{\circ} \mathrm{C} \text { and water plants are often found at the base and walls of the pool }\end{array}$ \\
Clear, slightly brackish, emit bubbles gas (more than gas at the location HS1), slight smell of sulfur. The hot \\
water temperature at the larger ponds were $450^{\circ} \mathrm{C}$ and plants are often found at the base and walls of the pool \\
Clear, slightly brackish, emit bubbles gas (more than gas at the location HS1 and HS2), smell of sulfur (stronger \\
than HS1 and HS2). The hot water temperature at the larger ponds were $62^{\circ} \mathrm{C}$ and plants are often found at the \\
base and walls of the pool \\
Clear, the temperature about $26^{\circ} \mathrm{C}$
\end{tabular}




\subsection{Geochemical analysis}

The manifestations of hot springs are located on the center and northern of research area which match with FFD map and have temperature are $43{ }^{\circ} \mathrm{C}, 45^{\circ} \mathrm{C}$, and $62{ }^{\circ} \mathrm{C}$. The result of geochemical analysis which conducted on two hot spring samples and one cold water sample are in Table 3 below:

Table 3. Laboratory data analysis of two hot water from three different hot springs and cold water.

\begin{tabular}{llll}
\hline \multicolumn{1}{c}{ Parameter } & \multicolumn{1}{c}{ HS 2 } & HS 3 & CW 1 \\
\hline $\mathrm{Ph}$ & 6.38 & 6.23 & 8.03 \\
$\mathrm{Ca}$ & 5.33 & 42.87 & 62.65 \\
$\mathrm{Mg}$ & 15.78 & 27.65 & 26.5 \\
$\mathrm{Na}$ & 87.95 & 124.43 & 89.25 \\
$\mathrm{~K}$ & 33.23 & 34.45 & 19.77 \\
$\mathrm{HCO}_{3}^{-}$ & 423.5 & 352.63 & 188.68 \\
$\mathrm{SO}_{4}^{-}$ & 28.15 & 14.2 & 10.35 \\
$\mathrm{Cl}^{-}$ & 163.59 & 202.54 & 185.3 \\
$\mathrm{~B}$ & $<0.003$ & $<0.003$ & $<0.003$ \\
$\mathrm{Li}$ & 0.007 & 0.004 & 0.003 \\
\hline \multicolumn{2}{r}{$*$ unit in mg/L (except pH) } &
\end{tabular}

Based on laboratory analysis of HS2, HS3, and CW1 have values that it show HS3 is feasible and can be used for further analysis.

\subsubsection{Water types and reservoir}

Water types based on the ratio of $\mathrm{Cl}^{-} \mathrm{SO}_{4}{ }^{2-}$ and $\mathrm{HCO}_{3}{ }^{-}$which can be shown in Table 4 below. The concentration ratio is plotted in a triangular diagram of Cl--SO4--HCO3- ions to know the type of hot water as shown in Diagram 1 below.

Table 4. Ratio concentration calculation of $\mathrm{Cl}^{-} \mathrm{SO}_{4}{ }^{2-}$ and $\mathrm{HCO}_{3}{ }^{-}$

\begin{tabular}{lll}
\hline \multicolumn{1}{c}{ Parameter } & \multicolumn{1}{c}{$\mathrm{mg} / \mathrm{l}$} & \multicolumn{1}{c}{$\%$} \\
\hline $\mathrm{CL}^{-}$ & 202.54 & 35.57 \\
$\mathrm{SO}_{4}{ }^{2-}$ & 14.2 & 2.49 \\
$\mathrm{HCO}_{3}{ }^{-}$ & 352.63 & 61.93 \\
\hline Total & 569.37 & 100 \\
\hline
\end{tabular}

The hot water of research area is categorized as bicarbonate water as shown on the triangular diagram below. The bicarbonate water sign that the hot water already mixed with their surrounding and have been moved away from the source [5].

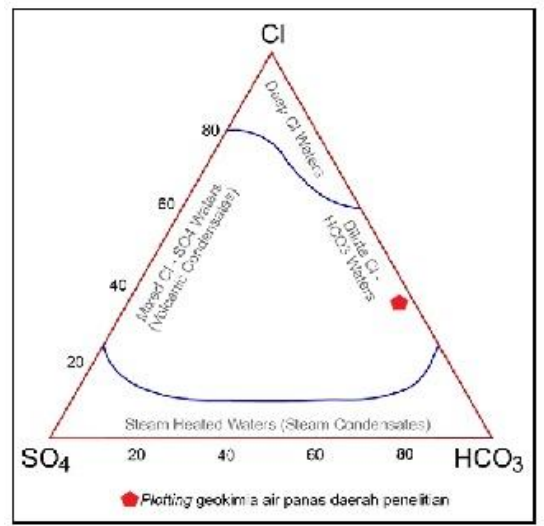

Diagram 1. Triangular diagram $\mathrm{Cl}^{-} \mathrm{SO}_{4}{ }^{2-}$ and $\mathrm{HCO}_{3}{ }^{-}$to know what kind of hot water in $\mathrm{HS} 3$ sample. 
The higher content of $\mathrm{HCO}_{3}$ than $\mathrm{SO}_{4}{ }^{2-}$ and $\mathrm{Cl}^{-}$show lateral flow mechanism which spread magmatic gas of $\mathrm{H}_{2} \mathrm{~S}$, $\mathrm{SO}_{2}$ or $\mathrm{CO}_{2}$ from the source to another place. The data was also used to to analyze the condition of hot water reservoir. Based on the ratio of $\mathrm{Na}^{+} / 1000, \mathrm{~K}^{+} / 100$ and $\sqrt{\mathrm{Mg}^{2+}}$, the hot water from HS3 is classified as an immature water this also in line with the result of the triangular diagram $\mathrm{Cl}^{-} \mathrm{SO}_{4}{ }^{2-}$ and $\mathrm{HCO}_{3}{ }^{-}$where the hot water has been interacted or mixing with ground water so the temperature of hot water reservoir is dificult to be determined. Generally the amount of $\mathrm{Mg}$ in high temperature fluid is about $(0.01$ to 0.1$) \mathrm{mg} / \mathrm{L}$. Enhancement of $\mathrm{Mg}$ is caused by the mixing of hot fluid to the groundwater which have high content of $\mathrm{Mg}$ about (1 to 40) $\mathrm{mg} / \mathrm{L}$. This cases are occured in the area where HS2 and HS3 are $15.78 \mathrm{mg} / \mathrm{L}$ and $27.65 \mathrm{mg} / \mathrm{L}$.

Tabel 5. Calculation of the concentraion ratio of $\mathrm{Na} / 1000-\mathrm{K} / 100-\sqrt{\mathrm{Mg}}$ of HS3 hot water.

\begin{tabular}{|c|c|c|}
\hline Parameter & 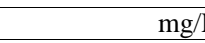 & $\%$ \\
\hline $\mathrm{Na}+/ 1000$ & 0.12 & 2.17 \\
\hline $\mathrm{K}+/ 100$ & 0.34 & 6.02 \\
\hline$\sqrt{ } \mathrm{Mg} 2+$ & 5.26 & 91.81 \\
\hline Total & 5.73 & 100 \\
\hline
\end{tabular}

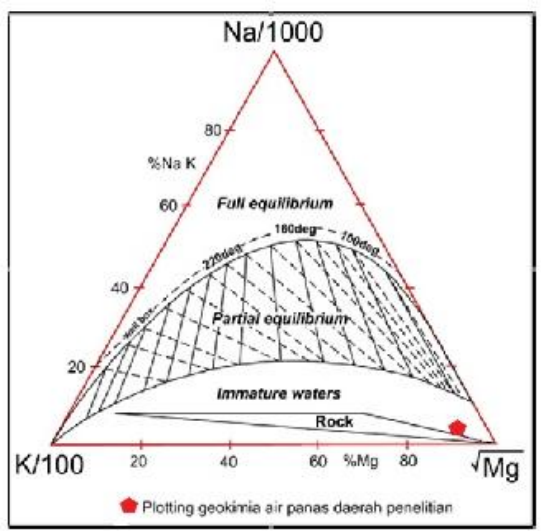

Diagram 2. $\mathrm{Na} / 1000-\mathrm{K} / 100-\sqrt{\mathrm{Mg}}$ chart to interprate the temperature of hot water reservoir of HS3 graphically.

Table 6. Calculation of the concentration ratio of $\mathrm{Li}-\mathrm{Cl} / 100-\mathrm{B} / 4$ of $\mathrm{HS} 3$ water.

\begin{tabular}{lll}
\hline Parameter & $\mathrm{mg} / \mathrm{L}$ & $\%$ \\
\hline $\mathrm{Cl}^{-} / 100$ & 1.6359 & 99.71 \\
$\mathrm{Li}^{+}$ & 0.004 & 0.24 \\
$\mathrm{~B} / 4$ & 0.00075 & 0.04 \\
Total & 1.64065 & 100 \\
\hline
\end{tabular}




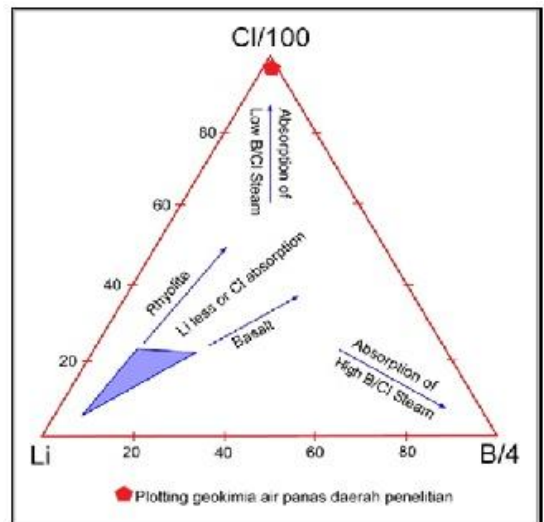

Diagram 3. Graph Li-Cl/100-B/4 of HS3 hot water.

\subsubsection{Hot water flow pattern}

Based on the chemical content of all the hot spring in the research area, all the hot spring reflected the outflow zone. The hot spring which have high number of $\mathrm{Cl}$ comparing $\mathrm{B}$ and $\mathrm{Li}$ represent that hot water is influenced by vulcanomagmatic activity [6]. The ratio between $\mathrm{Na} / \mathrm{K}$ and $\mathrm{K} / \mathrm{Mg}$ enhancing the fact that the hot spring is occurred in outflow zone. Therefore it can be concluded that there are interaction between hot water, ground water and the rocks around the surface. Manifestation that occurred and influenced by vulcanomagmatic activity is depend on relief and topography. The sulphate hot spring may be found at the top of the mountain or in upflow zone, while chloride and bicarbonate hot spring type can be found in relatively flat relief topography or in outflow zone.

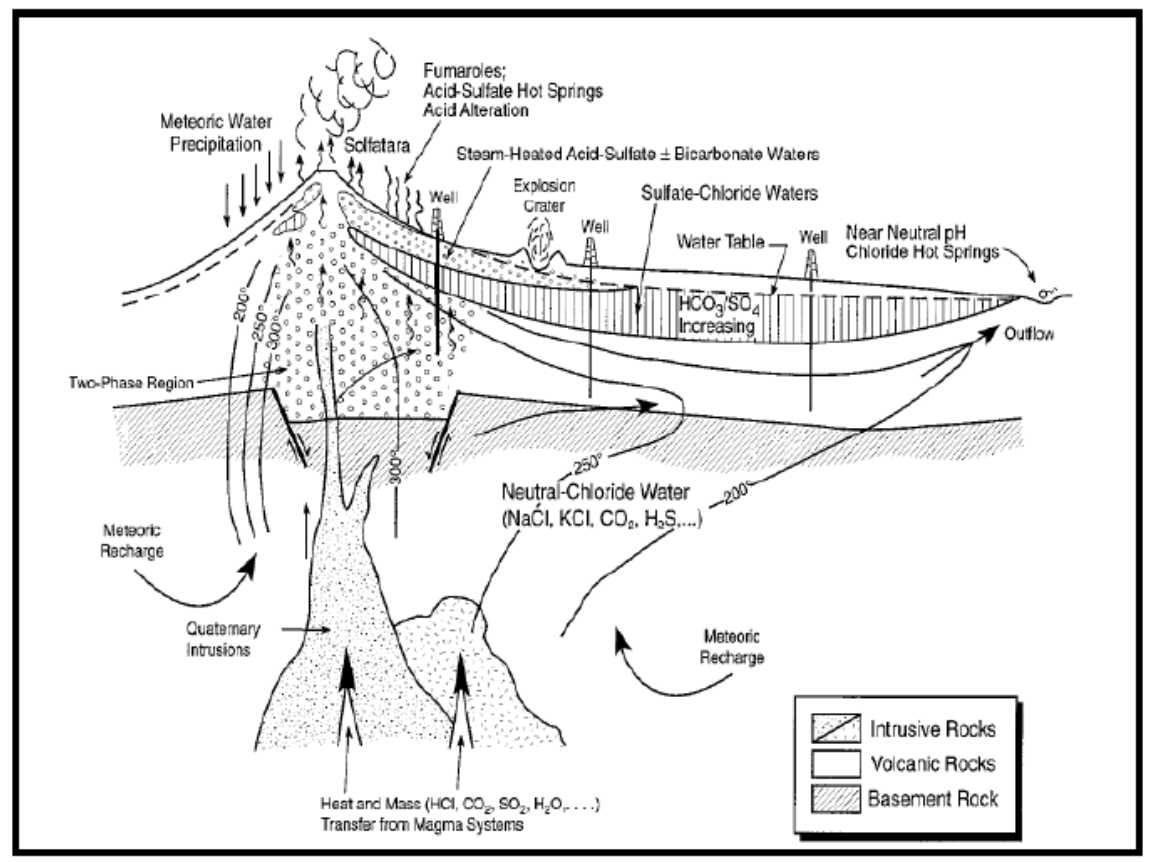

Figure 7. Conceptual model of geothermal system [6]. 
The conceptual model that describe the emergence of manifestation in research area can be used to understand the geothermal system in Slamet Mountain. The research area is about $+25 \mathrm{~km}$ far away from the top of Slamet Mountain which identified as an outflow zone.

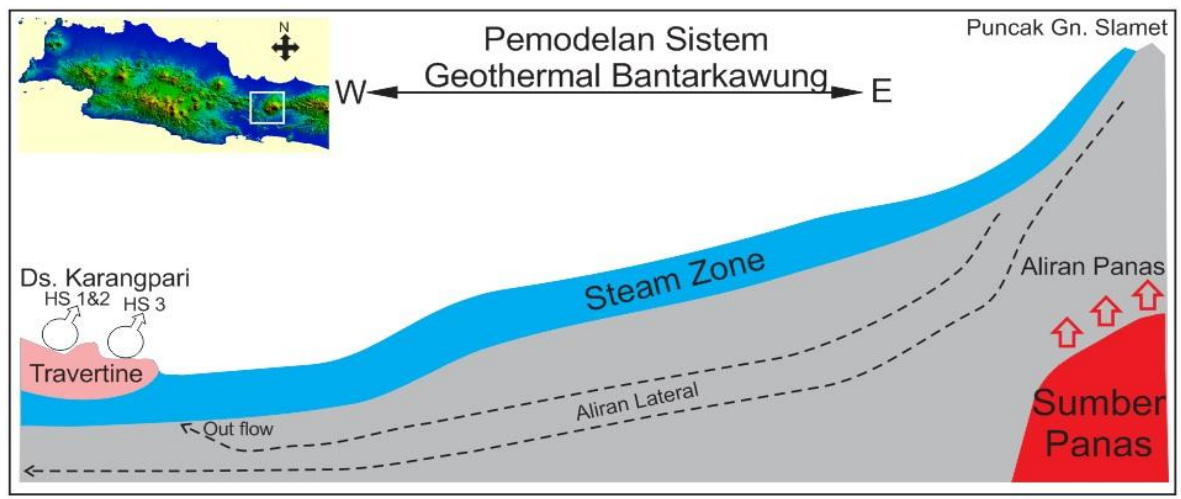

Figure 8. Schematic representation of the appearance of Bantarkawung hot springs manifestations.

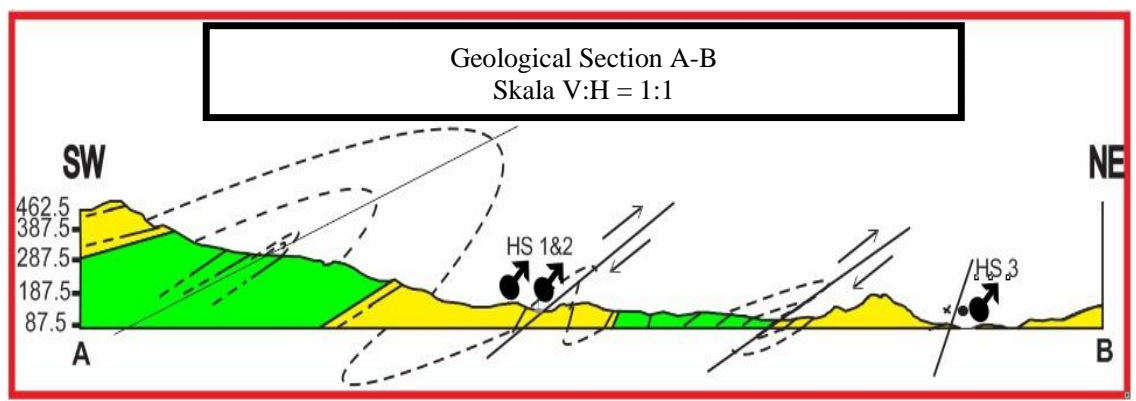

Figure 9. Geological section of research area.

\section{Conclusion}

The research area consist of two lithology units which are Mudstone unit and sandstone unit. Geothermal manifestation is hot spring water which appear on the center and northern research of area and accordance with FFD. Geological aspect which control the occurence of those manifestation are sandstone unit and structures like Pangebatan left thrust slip fault, Karangpari left thrust slip fault, Pangebatan right slip fault and Bisole right normal slip fault which lies on the research area. The type of hot water is bicarbonate water which indicating outflow zone of Slamet mountain geothermal system which is affected by vulcanomagmatic activity and have been interacted with ground water.

\section{Acknowledgements}

The authors are thankful to Geological Engineering, Jenderal Soedirman University Purwokerto especially for Mr. Sachrul Iswahyudi for support in this research.

\section{References}

[1] Kastowo (1975), "Peta Geologi, Lembar Majenang, Jawa, Skala 1:100.000”, Direktorat Geologi, Departemen Pertambangan Republik Indonesia. 
[2] Bujung, A.N. Cyrke, S. Alamte, M. Dicky, H. Febri ,dan S. Adjat. 2011. Identifikasi prospek panas bumi berdasarkan Fault and Fracture Density (FFD):Studi kasus Gunung Patuha, Jawa Barat, Jurnal Lingkungan dan Bencana Geologi, Vol. 2 No. 1 April 2011 2011: $67-75$.

[3] Nicholson, K. (1993), “Geothermal Fluids, Chemistry and Exploration Techniques”, Springer Verlag, Berlin, 15.

[4] Siswono, Yupi. Y.Listiawan, and R. Sahri. Galunggung Geothermal Prospect Condition: An Assesment For Further Development”Prosiding Seminar Kebumian Ke-6 Teknik Geologi Universitas Gadjah Mada, 11-12 Desember 2013.

[5] Iswahyudi, Sachrul. A. Widagdo, Subana, N. R. Herdianita (2013), “Outflow Zone Indication of Geothermal System In Paguyangan Hotspring, Brebes, Central Java” PROCEEDINGS, $2^{\text {nd }}$ ITB Geothermal Workshop 2013.

[6] Hochstein, M. P. dan Browne, P. R. L., 2000, Surface Manifestations of Geothermal Systems with Volcanic Heat Source. In Encyclopedia of Volcanoes (editor: Sirgudsson, H., Houghton, B., McNutt, S. R., Rymer, H., Stix, J.), Academic Press, San Diego. 